\title{
Recognitions of Terminal Care among Clinical Nurse Managers
}

\author{
Yeon-ja Kim
}

\begin{abstract}
When it comes to recognitions of terminal care among hospital nurse managers, this study was conducted with focus interviews targeting 15 nurse managers with over 10 years of experience at hemato-oncological centers, hospice wards, and intensive care units of three general hospitals with more than 300 wards in 3 cities of Korea, in order to explore the nature of experience using a phenomenological research methodology. Data analysis was based on Colaizzi(1978)'s phenomenological analysis method and 19 themes and 4 theme clusters were extracted from 64 meaning formations following the in-depth interviews with the subjects. It is supposed that the study findings would help in understanding the structure of nursing students, recognition on artistic aspects of care.
\end{abstract}

Keywords : terminal care, hospital nurse managers.

This work was supported by the National Research Foundation of Korea(NRF) grant funded by the Korea government(MSIT) (No. 2018-0118).

\section{INTRODUCTION}

The advancement in medical technology and science has been extending the human lifespan and this is leading to an increase in patients with terminal cancers and chronic conditions. In the light of this tendency, the importance of terminal care for helping patients spend the rest of their lives more comfortably and meaningfully is being highlighted(1). But existing terminal care in hospitals is not founded on a specific definition of the role of nurses and mostly, it is passive under the doctor's directions. Notwithstanding this realistic difficulty, most of the previous studies on terminal care have focused on the factors influencing terminal care practice, such as nurses' perception of death $(2,3)$, spirituality(4), and empathic ability(5), rather than fundamental experience of nurses performing terminal care. Humans have special significance in society all the time and it is impossible to study the nature and sociality of humans properly without taking human subjectivity into account(6). It is, therefore, very meaningful to study the nature of terminal care experience of nurses. This study was conducted to understand the nature of experience by looking into recognitions of terminal care among hospital nurses using a phenomenological research methodology.

\section{PROPOSED ALGORITHMS}

\subsection{Research Design}

This is a qualitative study to explore recognitions of terminal care among nurse managers using a phenomenological research methodology.

\subsection{Subject Selection and Ethical Consideration}

This study targeted 15 nurse managers, who have over 10 years of experience at hemato-oncological centers, hospice wards, and intensive care units of three general hospitals with more than 300 wards in 3 cities of Korea and agreed to take part in the study after hearing a full explanation of the study purpose and method.

\subsection{Data Collection}

The study was conducted with focus group interviews from October $1^{\text {st }} 2018$ to March $31^{\text {st }} 2019$. The interviews took place in quiet areas of the school so the subjects could feel easy and friendly.

\subsection{Data Analysis}

The statements of the subjects were analysed, based on Colaizzi(1978)'s phenomenological approach.

\subsection{Researchers' Preparation}

Researchers mastered the qualitative research method in the graduate courses to comprehend the nature of experience stated by the subjects, attended several academic conferences on qualitative research methods, and published a number of qualitative research papers in domestic and overseas journals.

\section{EXPERIMENTS AND RESULTS}

The answers of the subjects in the in-depth interviews were analysed to examine recognitions of terminal care among nurse managers. As a result, 19 themes and 4 theme clusters were acquired from 64 meaning formations[Table 1]. 
Table- I: Theme Construction

\begin{tabular}{|c|c|c|}
\hline Meaning Formation & Theme Cluster & Category \\
\hline Feel sorry for caregivers, who are not prepared. & \multirow{3}{*}{$\begin{array}{l}\text { Death education for caregivers is } \\
\text { required. }\end{array}$} & \multirow{14}{*}{$\begin{array}{l}\text { Future terminal care } \\
\text { strategies }\end{array}$} \\
\hline $\begin{array}{l}\text { Education is required for caregivers lacking terminal } \\
\text { care experience. }\end{array}$ & & \\
\hline Feel sorry for caregivers, who do not give up patients. & & \\
\hline $\begin{array}{l}\text { Assignment of role to notifying of the death time is } \\
\text { needed. }\end{array}$ & \multirow[b]{2}{*}{$\begin{array}{l}\text { Differentiated terminal care is } \\
\text { required. }\end{array}$} & \\
\hline $\begin{array}{l}\text { Terminal care strategies considering characteristics } \\
\text { of departments must be provided, since individual } \\
\text { departments define the death time differently. }\end{array}$ & & \\
\hline $\begin{array}{l}\text { Terminal care education for hospital nurses is } \\
\text { required. }\end{array}$ & \multirow{3}{*}{ Terminal care education is required. } & \\
\hline $\begin{array}{l}\text { Hospice nursing class for nursing students must be } \\
\text { invigorated. }\end{array}$ & & \\
\hline Feel thirsty due o unsatisfactory terminal care. & & \\
\hline Dying patients taken to requirements of caregivers & \multirow{3}{*}{ The needs of patients to prioritize } & \\
\hline Intentions of dying patients are ignored. & & \\
\hline Juvenile dying patients to read parents' countenance & & \\
\hline Want to help to improve psychological difficulties. & \multirow{3}{*}{ Spiritual care to reinforce } & \\
\hline It is unimaginable to provide emotional care. & & \\
\hline Be aware of spiritual needs, but there is a limit. & & \\
\hline $\begin{array}{l}\text { Feel rewarded, thanks to fellow doctors, who express } \\
\text { gratitude. }\end{array}$ & \multirow{2}{*}{$\begin{array}{l}\text { Feeling of reward by the expression o } \\
\text { gratitude }\end{array}$} & \multirow{6}{*}{$\begin{array}{l}\text { Factors encouraging } \\
\text { terminal care }\end{array}$} \\
\hline $\begin{array}{l}\text { Be encouraged to work by receiving greetings of } \\
\text { caregivers. }\end{array}$ & & \\
\hline Feel satisfied by doing the best to offer terminal care. & \multirow{2}{*}{$\begin{array}{l}\text { Satisfaction with fully provided } \\
\text { terminal care }\end{array}$} & \\
\hline Feel rewarded for belief-based terminal care. & & \\
\hline Realize the meaning of nursing after terminal care. & & \\
\hline $\begin{array}{l}\text { Feel satisfied when getting cursed because of the help } \\
\text { for patients. }\end{array}$ & Giving a positive meaning to nursing & \\
\hline Feel cold-hearted to follow the ward guidelines. & \multirow{3}{*}{ Losing humanity } & \multirow{17}{*}{$\begin{array}{l}\text { Obstacles to terminal } \\
\text { care }\end{array}$} \\
\hline Lose humanity following the rules. & & \\
\hline Feel indifferent to repeated death. & & \\
\hline Feel confused by sudden death. & \multirow{4}{*}{$\begin{array}{l}\text { Difficulty in providing consistent } \\
\text { terminal care }\end{array}$} & \\
\hline $\begin{array}{l}\text { It is difficult to provide terminal care when death is } \\
\text { just around the corner. }\end{array}$ & & \\
\hline Become care-oriented after sudden death. & & \\
\hline Family doctors' different ways of handling death & & \\
\hline $\begin{array}{l}\text { Watch a patient's death at a ward with general } \\
\text { patients. }\end{array}$ & \multirow{3}{*}{ Poor environments for terminal care } & \\
\hline There is no ward for dying patients. & & \\
\hline Other patients of a ward blame a dying patient. & & \\
\hline Feel confused by ambiguous DNR regulations. & \multirow{5}{*}{ A lack of awareness of palliative care } & \\
\hline Doctors avoid in the legally unprotected situation. & & \\
\hline There is a lack of confidence about medical practice. & & \\
\hline $\begin{array}{l}\text { Have difficulties due to doctors' inconsistent } \\
\text { attitudes. }\end{array}$ & & \\
\hline $\begin{array}{l}\text { Feel confused by a lack of trust in a doctor's patient } \\
\text { treatment. }\end{array}$ & & \\
\hline Uncertainty of life-sustaining treatment & \multirow[b]{2}{*}{ Confusing terminal care performance } & \\
\hline Terminal care begins late. & & \\
\hline
\end{tabular}




\begin{tabular}{|c|c|c|}
\hline Read a doctor's countenance. & & \\
\hline Miss the time for terminal care. & & \\
\hline Feel sorry for a doctor, who does not give up a patient. & & \\
\hline Have difficulties in controlling caregivers. & & \\
\hline $\begin{array}{l}\text { Feel confused, because I do not know the range of } \\
\text { help. }\end{array}$ & & \\
\hline Lack confidence about informing of the death time. & & \\
\hline $\begin{array}{l}\text { Lose confidence due to a lack of knowledge of } \\
\text { terminal care. }\end{array}$ & & \\
\hline Doctors avoid the death situation. & \multirow{7}{*}{ Difficulty in leading terminal care } & \\
\hline $\begin{array}{l}\text { Doctors shift responsibility onto other shoulders in a } \\
\text { difficult situation. }\end{array}$ & & \\
\hline $\begin{array}{l}\text { Feel helpless, because I cannot do anything for } \\
\text { patients suffering from pain. }\end{array}$ & & \\
\hline Proposal for patient treatment is not accepted. & & \\
\hline Face a limitation in providing belief-based care. & & \\
\hline $\begin{array}{l}\text { Have difficulties in taking care due to blind faith in } \\
\text { substitute food. }\end{array}$ & & \\
\hline Feel sorry to watch a patient's suffering. & & \\
\hline $\begin{array}{l}\text { Terminal care practice, which is not absurdly enough } \\
\text { to meet the needs of patients }\end{array}$ & \multirow{5}{*}{ A low level of terminal care } & \\
\hline $\begin{array}{l}\text { Have no time for terminal care due to busy working } \\
\text { schedules. }\end{array}$ & & \\
\hline $\begin{array}{l}\text { Have no leisure to think of anything except nursing } \\
\text { due to busy working schedules. }\end{array}$ & & \\
\hline $\begin{array}{l}\text { Feel hungry, because terminal care is not fully } \\
\text { provided. }\end{array}$ & & \\
\hline Trauma from unsolved death experience & & \\
\hline Want to avoid expected emotional difficulties. & \multirow{2}{*}{ Avoidance of emotional conflicts } & \\
\hline Avoid rapport building with DNR patients. & & \\
\hline Have no leisure to think of spiritual care. & \multirow{3}{*}{ Absence of spiritual care } & \multirow{7}{*}{$\begin{array}{l}\text { Reality of terminal care } \\
\text { to improve }\end{array}$} \\
\hline $\begin{array}{l}\text { Spiritual care, which is dependent on the demands of } \\
\text { patients }\end{array}$ & & \\
\hline Spiritual care, which is not fully provided & & \\
\hline $\begin{array}{l}\text { Feel skeptical, because I fail to fully perform terminal } \\
\text { care. }\end{array}$ & \multirow[t]{2}{*}{ Skepticism about nursing } & \\
\hline Regret doing this thing. & & \\
\hline $\begin{array}{l}\text { Feel confused at myself losing humanity due to the } \\
\text { burden of work. }\end{array}$ & \multirow[t]{2}{*}{ Settlement of ethical dilemma } & \\
\hline The death time not to be notified to patients & & \\
\hline
\end{tabular}

\section{CONCLUSION}

When it comes to recognitions of terminal care among nurse managers, this study was attempted to explore the nature of experience using a phenomenological research methodology. 19 themes and 4 theme clusters were extracted from 64 meaning formations following the in-depth interviews with the subjects. It is considered that the study findings above would help in understanding the structure of nurse managers' recognition on terminal care. In the future, there would be a need to develop a program to train nurse managers for enhancing a level of terminal care in the field of nursing, based on the recognitions of terminal care among nurse managers revealed in this study.

\section{REFERENCES}

1. Park. H.J, The Structural Equation Model on End-of-life Care Performance in Clinical Nurses, doctor's thesis, Inje University; p.1-69, 2017.

2. Jang. J.Y, Hospice care stress and death awareness of general ward nurses, master's thesis, Hanyang University, p.1-35, 2016.

3. Shin H.J, The Influence of Performance of Terminal Care on Professionalism and Good Death Awareness in Clinical Nurses, master's thesis, Chungji University, p.1-28, 2011.

4. Kim E.H, The Mediating Effect of compassionate competence on the Relationship between Spirituality and attitude toward caring for dying patients of general hospital nurses, master's thesis, Yonsei University, p.1-51, 2018.

5. Noh M.H, Effects of End-of-Life Care Performance toward Shared Medical Decision Making and Empathy Competence, master's thesis, Daegu Catholic University, p1-28, 2017.

\section{Published By:}

Blue Eyes Intelligence Engineering

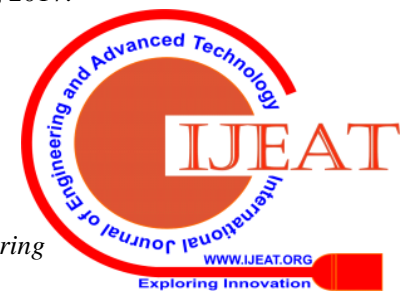

